\title{
Alternative products to control late season diseases in soybeans
}

\author{
Gislaine Gabardo' ${ }^{*}$ (D) Maristella Dalla Pria ${ }^{1}$ (D) \\ Henrique Luis da Silva² (D) Mônica Gabrielle Harms ${ }^{1}$
}

${ }^{1}$ Departmento de Fitotecnia e Fotossanidade, Universidade Estadual de Ponta Grossa (UEPG), 84030-900, Ponta Grossa, PR, Brasil. E-mail: gislainegabardo2007@yahoo.com.br. "Corresponding author.

${ }^{2}$ Instituto de Desenvolvimento Rural do Paraná (IDR-Paraná), Ponta Grossa, PR, Brasil.

\begin{abstract}
In the last crop seasons, the complex of late season diseases (CLSD) of soybean (Glycine max L. (Merrill)), has been causing considerable reductions in the crop yield. Currently, there are no cultivars resistant to all pathogens that causes CLSD. The present study evaluated the effect of applying the acibenzolar-S-methyl resistance inducer, alternative products and fungicide on the severity of CLSD in the soybean cultivar BMX Potencia RR during the 2013/2014 and 2014/2015 crops, in the field. The treatments for the experiments were: 1 control (water); 2 - acibenzolar-S-methyl; 3 - calcium; 4 - micronutrients: copper, manganese and zinc; 5 - micronutrients: manganese, zinc and molybdenum; 6 - nitrogen-potassium fertilizer; 7 - Ascophyllum nodosum and 8 - azoxystrobin + cyproconazole with the addition of the adjuvant. Four applications of alternative products and two of fungicide were carried out in both harvests. A diagrammatic scale assessed the severity of CLSD at the phenological stage R7.1. The acibenzolar-S-methyl resistance inducer, alternative products (macro and micronutrients) and A. nodosum had no effect on the severity of CLSD in the two harvests. The fungicide (azoxystrobin + cyproconazole) reduced the severity of CLSD and prevented damage to productivity in both experiments.

Key words: Glycine max L., Septoria glycines, Cercospora kikuchii, severity.
\end{abstract}

Produtos alternativos para o controle de doenças de final de ciclo na soja

RESUMO: Nas últimas safras, o complexo de doenças de final de ciclo (DFC) da soja (Glycine max L. (Merrill)), vem provocando reduções consideráveis no rendimento da cultura. Atualmente, não há variedades resistentes a todos os patógenos causadores das DFC. O objetivo do presente trabalho foi avaliar o efeito da aplicação do indutor de resistencia acibenzolar-S-methyl, produtos alternativos e fungicida na severidade de DFC na cultivar de soja BMX Potência RR durante as safras 2013/2014 e 2014/2015, em campo. Os tratamentos para os experimentos foram: 1 - testemunha (água); 2 - acibenzolar-S-methyl; 3 - cálcio; 4 - micronutrientes: cobre, manganês e zinco; 5 micronutrientes: manganês, zinco e molibdênio; 6 - adubo NK; 7 - Ascophyllum nodosum e 8 - azoxistrobina + ciproconazol com adição do adjuvante. Foram realizadas quatro aplicações dos produtos alternativos e duas do fungicida, nas duas safras. A severidade de DFC foi avaliada por escala diagramática no estádio fenológico R7.1. O indutor de resistência acibenzolar-S-methyl, os produtos alternativos (macro e micronutrientes) e A. nodosum não apresentaram efeito sobre a severidade das DFC nas duas safras. O fungicida (azoxistrobina + ciproconazol) reduziu a severidade das DFC e evitou danos a produtividade nos dois experimentos.

Palavras-chave: Glycine max L., Septoria glycines, Cercospora kikuchii, severidade.

\section{INTRODUCTION}

Soybean (Glycine max (L.) Merrill) is one of the most important crops in Brazilian agribusiness (ZDZIARSKI et al., 2019). However, the entire production success can be compromised by diseases occurrence, among which late season diseases stand out (ROLLING et al., 2020; LIN et al., 2020).

Late season leaf diseases in soybean are caused by the fungi Septoria glycines (Hemmi) and Cercospora kikuchii (Matsu. \& Tomoyasu) (MARTINS et al., 2004) and are present in all soy producing regions in Brazil. They are considered a "complex of late season diseases" (CLSD) because they occur simultaneously and due to the difficulties they present in individual assessments, causing premature crop defoliation, which can reduce soybean productivity by more than 20\% (GODOY \& CANTERI, 2004).

In Brazil, fungicides have been used in soybean crops to control CLSDs (GODOY et al., 2009; JULIATTI et al., 2019). However, the constant need to control diseases with fungicides has caused serious imbalances in the environment. Therefore, it is necessary to search for more rational alternatives 
for an adequate disease management program by using resistance inducers and alternative products (CAVALCANTI et al., 2005).

Resistance induction is defined as the activation of the plant's ability to defend itself against a broad spectrum of pathogens after appropriate stimulation (DIAS et al., 2019). Unlike gene-to-gene interactions that govern specific genetic resistance, the so-called "acquired systemic resistance" (ASR) is not specific and is expressed throughout the plant after being induced (DALLAGNOL et al., 2006). The non-specific character of resistance induction provides a simultaneous increase in the level of basal resistance for many pathogens, which can be beneficial under field conditions, where multiple pathogens may be present (JACKSON et al., 2000; WRÓBEL-KWIATKOWSKA et al., 2004), as is the case with CLSDs.

Inducers of plant defense mechanisms, biotic or abiotic, may represent an alternative and complementary method of control. Among the agents that have activating properties of resistance mechanisms in plants are acibenzolar-S-methyl (ASM) (CAVALCANTI et al., 2005; ARANTES et al., 2020).

ASM is a synthetic compound, a functional analogue of salicylic acid. It acts mainly in the activation of genes whose expression results in proteins production such as peroxidases, glucanases and chitinases, as well as in the production of phytoalexins and changes in the cell wall by lignification, conferring resistance to the attack of phytopathogens (WRÓBEL-KWIATKOWSKA et al., 2004; DUARTE et al., 2009; DIAS et al., 2019).

Other alternative products such as the use of micro and macronutrients and the brown seaweed Ascophyllum nodosum (Linnaeus) Le Jolis are being studied in the control of diseases in soybean (TANDON \& DUBEY, 2015; STADNIK \& FREITAS, 2014; GABARDO et al., 2020). These products can act in protection, promoted by balanced mineral nutrition. As a result, the formation of an efficient physical barrier, with inhibition of hyphae penetration or better control of the permeability of the cytoplasmic membrane (FURTADO et al., 2020). In addition to the possibility of also acting as activators of plant resistance (JACKSON et al., 2000).

Within this context, the present study evaluated the effect of foliar application of acibenzolar-S-methyl, alternative products and fungicide on the severity of CLSD in the field in the cultivar BMX Potência RR, in no-tillage system on straw, in the $2013 / 2014$ and $2014 / 2015$ crops.

\section{MATERIALS AND METHODS}

The experiment was carried out in Ponta Grossa-PR $\left(25^{\circ} 13^{\prime}\right.$ latitude and $50^{\circ} 03^{\prime}$ 'longitude, at an altitude of $900 \mathrm{~m}$ above sea level). The climate is classified as humid subtropical mesothermal (Cfb) and the soil in the place as typical Eutrophic Haplic Cambisol, clay texture (EMBRAPA, 2018).

Before installing the experiment, soil samples were collected for chemical analysis: $\mathrm{pH}$ in water 5.9, P (Mehlich 1): $2.2 \mathrm{mg} \cdot \mathrm{dm}^{-3}, \mathrm{~K}: 70 \mathrm{mg} \cdot \mathrm{dm}^{-3}, \mathrm{~S}$ (phosphate monocalcium in acetic acid): $9.8 \mathrm{mg} . \mathrm{dm}^{-3}$, Ca: 1.8 cmolc. $\mathrm{dm}^{-3}, \mathrm{Mg}: 1.3 \mathrm{cmolc}^{-\mathrm{dm}^{-3}}$, effective CTC (t): $4.3 \mathrm{cmolc}^{\mathrm{dm}}{ }^{-3}$, MO: 3.6 dag. $\mathrm{kg}^{-1}$. The average monthly temperatures, total monthly precipitation and the average humidity in the experiments area in the period were collected by an agrometeorological station located close to the experimental field (Table 1).

Sowing of soybean cultivar BMX Potência $\mathrm{RR}$ was carried out in a no-tillage system, on wheat straw, on $12 / 18 / 2013$ and on $12 / 16 / 2014$, using $0.45 \mathrm{~m}$ line spacing with 15 seeds per meter to obtain density of 12 plants $\mathrm{m}^{-1}$ and final population of 250,000 plants $\mathrm{ha}^{-1}$. The monitoring weeds and pests occurrence was weekly, and control was carried out according to the crop needs.

The experimental design adopted was randomized blocks, with eight treatments and four replications, in plots measuring $6.0 \times 4.0 \mathrm{~m}\left(24 \mathrm{~m}^{2}\right)$, with a useful area of $5.0 \times 1.8 \mathrm{~m}\left(9.0 \mathrm{~m}^{2}\right)$. The treatments were foliar application of the products: 1 - Control (water); 2 - acibenzolar-S-methyl (Bion $\left.500 \mathrm{WG}^{\circledR}\right)(25$ g p.c. ha $\left.{ }^{-1}\right) ; 3$ - calcium $\left(\right.$ Max Fruit $\left.{ }^{\circledR}\right)\left(0.75\right.$ L p.c. ha $\left.{ }^{-1}\right)$; 4 - micronutrients: copper, manganese and zinc (Wert Plus $\left.^{\circledR}\right)\left(0.75\right.$ L p.c. ha $\left.{ }^{-1}\right) ; 5$ - micronutrients: manganese, zinc and molybdenum $\left(\mathrm{V6}^{\circledR}\right)\left(0.75 \mathrm{~L}^{\circledR}\right.$.c. ha $\left.{ }^{-1}\right) ; 6$ - NK fertilizer (Hight Roots ${ }^{\circledR}$ ) $\left(0.75\right.$ L p.c. ha $\left.{ }^{-1}\right) ; 7$ - seaweed Ascophyllum nodosum $\left(\right.$ Acadian $\left.^{\circledR}\right)\left(2.0\right.$ L p.c. ha $\left.{ }^{-1}\right)$ and 8 - azoxystrobin + cyproconazole (Priori XTRA ${ }^{\circledR}$ ) (300 $\mathrm{mL}$ p.c. ha $^{-1}$ ) with the addition of Nimbus adjuvant $(0.5 \% \mathrm{v} / \mathrm{v})$. The development of soybean culture was accompanied by the phenological scale proposed by FEHR \& CAVINESS (1981).

Four applications of alternative products were carried out at phenological stages V3 ( $2^{\text {nd }}$ developed trefoil), V6 (fifth developed trefoil), R1 (beginning of flowering) and R5.1 (grains that are noticeable to the touch (10\% of grain) and two applications of fungicide in the phenological stages R1 and R5.1. The applications were carried out using a knapsack sprayer with constant pressure $\left(\mathrm{CO}_{2}\right)$, equipped with a bar with simultaneous arrangement of four flat fan spray nozzles (XR 11002) spaced 0.50 $\mathrm{m}$ apart and pressure of $3 \mathrm{~kg} \mathrm{~cm}$. A flow rate of 250 
Table 1 - Average temperature $\left({ }^{\circ} \mathrm{C}\right)$, total precipitation $(\mathrm{mm})$ and average humidity $(\%)$ in the months of the experiment with soybean (Glycine max) to control complex of late season diseases (Septoria glycines e Cercospora kikuchii). Ponta Grossa/PR, 2013/2014 and 2014/2015 growing.

\begin{tabular}{|c|c|c|c|c|c|}
\hline Month & December & January & February & March & April \\
\hline Average temperature $\left({ }^{\circ} \mathrm{C}\right)$ & 20.9 & 21.7 & 21.7 & 20.0 & 18.2 \\
\hline Total precipitation (mm) & 149.2 & 262.8 & 137.2 & 164.0 & 93.0 \\
\hline Average humidity (\%) & 82.8 & 83.4 & 82.3 & 87.4 & 85.9 \\
\hline \multicolumn{6}{|l|}{ 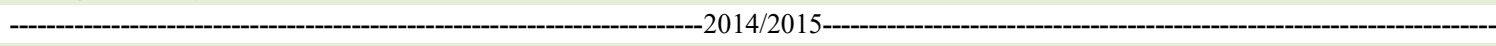 } \\
\hline Month & December & January & February & March & April \\
\hline Average temperature $\left({ }^{\circ} \mathrm{C}\right)$ & 20.6 & 22.0 & 20.7 & 19.9 & 18.2 \\
\hline Total precipitation $(\mathrm{mm})$ & 353.4 & 125.6 & 234.8 & 168.5 & 65.8 \\
\hline Average humidity (\%) & 83.5 & 81.9 & 85.4 & 87.9 & 84.1 \\
\hline
\end{tabular}

Data provided by the Basf weather station (Badische Anilin \& Soda Fabrik).

$\mathrm{L} \mathrm{ha}^{-1}$ was used for all treatments. A flow rate of 250 $\mathrm{L} \mathrm{ha}^{-1}$ was used for all products.

The CLSD evaluations were carried out at the phenological stage R7.1, using the diagrammatic scale of the late season soybean diseases (C. kikuchii and S. glycines) proposed by MARTINS et al. (2004). The data were subjected to analysis of normality (ShapiroWilk) and equality of variance (Bartlett's test), at the 5\% level of significance. Afterwards, the F test was applied in the analysis of variance (ANOVA) with the test of separation of means the Scott-Knott test, also at the level of $5 \%$ of significance. The analyzes were performed with the aid of the statistical software R.

\section{RESULTS AND DISCUSSION}

Diseases are closely linked to climatic conditions, that is, temperature and humidity. Endof-cycle diseases manifest themselves with greater intensity when the temperature varies between 20 and $30^{\circ} \mathrm{C}$ and when the rains are frequent and above normal (KUDO et al., 2011). In the present experiment, favorable climatic conditions occurred for the occurrence of CLSD (Table 1). CARMONA et al. (2010), comment that the non-occurrence of the required climatic conditions can disadvantage the onset of diseases, and it is not necessary to use control strategies.

CLSDs occurred in both seasons (Table 2). The severity of the disease ranged from 3.25 to $35.46 \%$ in the 2013/2014 harvest and treatments with ASM, macronutrients, micronutrients and seaweed did not differ from the control. Treatment with fungicide (azoxystrobin + cyproconazole) controlled the disease, reducing its severity by $90.73 \%$.
In $2014 / 2015$ the disease severity ranged from 20.02 to $40.52 \%$. The obtained results were similar to the first harvest, as treatments with ASM, macronutrients, micronutrients and seaweed did not differ from the control. The treatment with the fungicide differed from the control, reducing severity of CLSDs by $50.59 \%$ (Table 2 ).

DALLAGNOL et al. (2006), obtained a significant difference in reducing severity of CLSD using ASM in soybean cultivars RS 10, IAS 5 and CD 201. The authors concluded that there is variation between the responses of each cultivar. Which may justify the lack of response, as the cultivar used in the present experiment is BMX Potência RR.

DUARTE et al. (2009), carried out three applications in the phenological stages R1, R4 and R5.4 of ASM (125g de a.i. ha $\mathrm{a}^{-1}$ ) obtained intermediate control (between the control and the fungicide) of Asian rust (Phakopsora pachyrhizi H. Sydow \& P. Sydow), but the authors did not evaluate CLSD. While COSTA et al. (2007), obtained efficient control of rust (Hemileia vastatrix Berk \& Br) in coffee culture (Coffea arabica L.) by ASM.

With regard to foliar fertilizers, according to MCDONALD et al. (2001), they can correct deficiencies, increase crops with low yield, increase growth and the speed of growth of plants. However, the application of macros and micronutrients in the present experiment did not affect the severity of CLSD (Table 2).

The applications of $A$. nodosum did not reduce the severity of CLSDs, in both harvests (Table 2). GABARDO et al. (2020), did not observe a severity reduction in Asian rust with application 
Table 2 - Severity (\%) of complex of late season diseases (Septoria glycines e Cercospora kikuchii) in the 2013/2014 and 2014/2015 crops, in different treatments performed on soybeans (Glycine max), cultivar BMX Potência RR.

\begin{tabular}{|lccc}
\hline Treatment & $2013 / 2014$ & $2014 / 2015$ \\
\hline 1-Witness (water) & $35.06 \mathrm{a}^{*}$ & $40.52 \mathrm{a}$ \\
\hline 2-Acibenzolar-S-methyl & $31.50 \mathrm{a}$ & $38.45 \mathrm{a}$ \\
\hline 3-Macronutrients: Ca & $32.95 \mathrm{a}$ & $40.95 \mathrm{a}$ \\
\hline 4-Micronutrients: Cu, Mn, Zn & $29.55 \mathrm{a}$ & $35.98 \mathrm{a}$ \\
\hline 5-Micronutrients: Mn, Zn, Mo & $32.87 \mathrm{a}$ & $42.18 \mathrm{a}$ \\
\hline 6-NK fertilizer & $35.46 \mathrm{a}$ & $38.23 \mathrm{a}$ \\
\hline 7-Ascophyllum nodosum & $30.22 \mathrm{a}$ & $41.37 \mathrm{a}$ \\
\hline 8-azoxystrobin + cyproconazole & $3.25 \mathrm{~b}$ & $20.02 \mathrm{~b}$ \\
\hline C. V. (\%) & 21.79 & 15.42 \\
\hline
\end{tabular}

*Averages followed by the same lower case letter in the column do not differ by the Scott-Knott test at $5 \%$ significance; C.V. $=$ coefficient of variation.

of seaweed extract. TANDON \& DUBEY (2015), using seaweed extract in the field, observed positive effects on the soybean culture, such as greater number of leaves, pods per plant and productivity; however, the authors did not evaluate the occurrence and severity of CLSDs.

CLSDs were more severe in the second harvest (Table 2), probably due to the greater volume of precipitation ( $806.2 \mathrm{~mm}$ in the $2013 / 2014$ harvest and $948.1 \mathrm{~mm}$ in the 2014/2015 harvest) (Table 1). The control severity was $34.06 \%$ in the first harvest and $40.52 \%$ in the second harvest. In the treatment with the fungicide, it was 3.25 and $20.02 \%$, in the first and second harvest, respectively. Under conditions of higher disease severity, the fungicide efficiency decreased from 90.73 to $50.59 \%$ (Table 2).
DALLAGNOL et al. (2006) reported that two applications of the fungicide (azoxystrobin) in soybean culture, reduced the severity of CLSDs. The same authors tested the association of the resistance inducer (ASM) with the fungicide diphenoconazole, concluding that the best results were obtained with applications of diphenoconazole + ASM. Future experiments are needed using the combination of alternative products and fungicide resistance inducers.

In research, there was no significant difference in productivity using ASM, micro and macronutrients (Table 3). CARVALHO \& OLIVEIRA (2013), obtained similar results in soybean culture, where productivity in the treatment with ASM, with 3 applications, not differed from the control and the treatment with fungicide (azoxystrobin +

Table 3 - Productivity $\left(\mathrm{Kg} \mathrm{ha}^{-1}\right)$ as a function of treatments performed on soybeans (Glycine max), cultivar BMX Potência RR. Ponta Grossa / PR, 2013/2014 and 2014/2015 crops.

\begin{tabular}{lcc}
\hline Treatment & $2013 / 2014$ & $2014 / 2015$ \\
\hline 1- Witness (water) & $1400.81 \mathrm{~b}^{*}$ & $1308.28 \mathrm{~b}$ \\
2- Acibenzolar-S-methyl & $1716.89 \mathrm{~b}$ & $1325.49 \mathrm{~b}$ \\
\hline 3- Macronutrients: Ca & $1667.86 \mathrm{~b}$ & $1334.22 \mathrm{~b}$ \\
4- Micronutrients: Cu; Mn; Zn & $1900.90 \mathrm{~b}$ & $1529.01 \mathrm{~b}$ \\
\hline 5- Micronutrients: Mn; Zn; Mo & $1737.70 \mathrm{~b}$ & $1307.56 \mathrm{~b}$ \\
6- NK fertilizer & $1580.71 \mathrm{~b}$ & $1310.18 \mathrm{~b}$ \\
7- Ascophyllum nodosum & $1453.11 \mathrm{~b}$ & $1278.73 \mathrm{~b}$ \\
\hline 8- azoxystrobin + cyproconazole & $3025.72 \mathrm{a}$ & $2303.46 \mathrm{a}$ \\
CV (\%) & 12.13 & 10.27 \\
\hline
\end{tabular}

*Averages followed by the same lower case letter in the column do not differ by the Scott-Knott test at $5 \%$ significance; C.V. = coefficient of variation.

Ciência Rural, v.52, n.2, 2022. 
cyproconazole) differed from the control. SILVA et al. (2013) reported that treatment with ASM associated with fungicide (pyraclostrobin + epoxiconazole), in soy, prevented damage to productivity. However, in this research in relation to isolated application of ASM, there were no differences in productivity (Table 3).

\section{CONCLUSION}

The acibenzolar-S-methyl resistance inducer, alternative products (calcium; micronutrients: copper, manganese and zinc; micronutrients: manganese, zinc and molybdenum; NK fertilizer) and seaweed (Ascophyllum nodosum) had no effect on late season leaf disease severity in both harvests. The fungicide (azoxystrobin + cyproconazole) was the only one that controlled CLSDs and prevented damage to productivity in both crops.

\section{ACKNOWLEDGEMENTS}

This study was financed in part by the Coordenação de Aperfeiçoamento de Pessoal de Nível Superior - Brasil (CAPES) - Finance Code 001

\section{DECLARATION OF CONFLICT OF INTEREST}

The authors declare no conflict of interest. The founding sponsors had no role in the design of the study; in the collection, analyses, or interpretation of data; in the writing of the manuscript, and in the decision to publish the results.

\section{AUTHORS' CONTRIBUTIONS}

The authors contributed equally to the manuscript.

\section{REFERENCES}

ARANTES, M. R. et al. Gene expression during development and overexpression after Cercospora kikuchii and salicylic acid challenging indicate defensive roles of the soybean toxin. Plant Cell Reports, v.39, p.1-14, 2020. Available from: <https://doi. org/10.1007/s00299-020-02523-1>. Accessed: Aug. 05, 2020. doi: $10.1007 / \mathrm{s} 00299-020-02523-1$.

CARMONA, M. et al. Relación entre la precipitación registrada en estados reproductivos de la soja y la severidad de Septoria glycines y Cercospora kikuchii. Tropical plant pathology, v.35 n.2, p.71-78, 2010. Available from: <https://doi.org/10.1590/S198256762010000200001>. Accessed: Jul. 08, 2020. doi: 10.1590/ S1982-56762010000200001

CARVALHO, B. O. et al. Action of defense activator and foliar fungicide on the control of Asiatic rust and on yield and quality of soybean seeds. Journal of Seed Science, v.35, n.2, p.198 206, 2013. Available from: <https://doi.org/10.1590/S2317-
15372013000200009>. Accessed: Jan. 13, 2021. doi: 10.1590/ S2317-15372013000200009.

CAVALCANTI, F. R. et al. Activities of antioxidant enzymes and photosynthetic responses in tomato pre-treated by plant activators and inoculated by Xanthomonas vesicatoria. Physiological and Molecular Plant Pathology, v.68, ed.4-6, p.198-208, 2005. Available from: <https://doi.org/10.1016/j.pmpp.2006.11.001>. Accessed:Aug. 05,2020. doi: doi.org/10.1016/j.pmpp.2006.11.001.

COSTA, M. J. et al. Avaliação de produtos alternativos no controle da ferrugem do cafeeiro. Fitopatologia Brasileira, v.32, n.2, p.150-155, 2007. Available from: <http://dx.doi.org/10.1590/ S0100-41582007000200010>. Accessed: Aug. 05, 2020. doi: $10.1590 / \mathrm{S} 0100-41582007000200010$.

DALLAGNOL, L. J. et al. Use of Acibenzolar-S-Methyl to control foliar diseases of soybean. Summa Phytopathologica, v.32 n.3, p.255-259, 2006. Available from: <http://dx.doi.org/10.1590/ S0100-54052006000300007>. Accessed: Aug. 03, 2020. doi: 10.1590/S0100-54052006000300007.

DIAS, R. D. C. et al. Ácido salicílico e acibenzolar-S-methyl como atenuadores de fitointoxicação causada pelo chlorimuronethyl na cultura da soja. Revista de Ciências Agrárias, v.42, n.2, p.141-150, 2019. Available from: <http://dx.doi.org/10.19084/ rca.16031>. Accessed: Aug. 03, 2020. doi: 10.19084/rca.16031.

DUARTE, H. D. S. S. et al. Silicato de potássio, acibenzolarS-metil e fungicidas no controle da ferrugem da soja. Ciência Rural, v.39, n.8, p.2271-2277, 2009. Available from: <https:// doi.org/10.1590/S0103-84782009000800001> Accessed: Jul. 15, 2020. doi: 10.1590/S0103-84782009000800001.

EMBRAPA-Empresa Brasileira de Pesquisa Agropecuária. Centro nacional de Pesquisa de Solos. Sistema brasileiro de classificação de solos, Rio de Janeiro, p. 306, 2018.

FEHR, W. R.; CAVINESS, C. E. Stage of soybean development. Ames: Iowa State University, 1981. (Special report 80, March).

FURTADO, E. B. et al. Curative and protective action of organic and inorganic compounds in the control of Microsphaera diffusa in soybean. Revista de Ciências Agroveterinárias, v.19, n.1, p.104-108, 2020. Available from: < https://doi.org/10 $.5965 / 223811711912020104>$. Accessed: Aug. 06, 2020. doi: $10.5965 / 223811711912020104$.

GABARDO, G. et al. Alternative products on Asian soybean rust control and their influence on defoliation, productivity and yield components. Summa Phytopathologica, v.46, n.2, p.98-104, 2020. Available from: <https://doi.org/10.1590/0100-5405/231561>. Accessed: Aug. 06, 2020. doi: 10.1590/0100-5405/231561.

GODOY, C. V.; CANTERI, M. G. Efeito da severidade de oídio e crestamento foliar de cercospora na produtividade da cultura da soja. Fitopatologia Brasileira, v.29, n.5, p.526531, 2004. Available from: <http://www.scielo.br/scielo. php? script $=$ sci_arttext\&pid $=$ S0100-41582004000500009\&lng $=$ en\&nrm=iso $>$. Accessed: Aug. 02, 2020. doi: 10.1590/S010041582004000500009 .

GODOY, C. V. et al. Eficiência do controle da ferrugem asiática da soja em função do momento de aplicação sob condições de epidemia em Londrina, PR. Tropical Plant Pathology, v.34, n.1, p.56-61, 2009. Available from: <https://doi.org/10.1590/S1982- 
56762009000100011>. Accessed: Aug. 06, 2020. doi: 10.1590/ S1982-56762009000100011.

JACKSON, T. J. et al. Action of the fungicide phosphite on Eucalyptus marginata inoculated with Phytophthora cinnamomi. Plant Pathology, v.49, n.1, p.147-154, 2000. Available from: $<$ https://doi.org/10.1046/j.1365-3059.2000.00422.x>. Accessed: Jul. 18, 2020. doi: 10.1046/j.1365-3059.2000.00422.x.

JULIATTI, F. C. et al. Characterization of soybean genotypes showing partial resistance to soybean rust. Summa Phytopathologica, v.45, n.3, p.313-319, 2019. Available from: $<$ https://doi.org/10.1590/0100-5405/190552>. Accessed: Aug. 06, 2020. doi: 10.1590/0100-5405/190552.

KUDO, Â. S. et al. Aerobiology of Cercospora kikuchii. Ciência Rural, v.41, n.10, p.1682-1688, 2011. Available from: <http:// dx.doi.org/10.1590/S0103-84782011005000128>. Accessed: Jul. 15, 2020. doi: 10.1590/S0103-84782011005000128.

LIN, H. A. et al. Characterization of Septoria brown spot disease development and yield effects on soybean in Illinois. Canadian Journal of Plant Pathology, p.1-11, 2020. Available from: $<$ https://doi.org/10.1080/07060661.2020.1755366>. Accessed: Aug. 02, 2020. doi:10.1080/07060661.2020.1755366.

MARTINS, M. C. et al. Escala diagramática para a quantificação do complexo de doenças foliares de final de ciclo em soja Fitopatologia Brasileira, v.29, n.2, p.179-184, 2004. Available from: <http://dx.doi.org/10.1590/S0100-41582004000200009>. Accessed: Jul. 08, 2020. doi: 10.1590/S0100-41582004000200009.

McDONALD, A. E. et al. Phosphite (phosphorous acid): its relevance in the environment and agriculture and influence on plant phosphate starvation response. Journal of plant nutrition, v.24, n.10, p.1505-1519, 2001. Available from: $<$ https://doi.org/10.1081/ PLN-100106017>. Accessed: Aug. 02, 2020. doi: 10.1081/PLN100106017.
ROLLING, W. et al. Genome-wide association analyses of quantitative disease resistance in diverse sets of soybean [Glycine $\max$ (L.) Merr.] plant introductions. Plos one, v.15, n.3, 2020. Available from: <https://journals.plos.org/plosone/ article?id=10.1371/journal.pone.0227710>. Accessed: Aug. 02, 2020. doi: 10.1371/journal.pone.0227710.

SILVA, O. C.; A.;et al.,. Fontes de fosfito e acibenzolar-S-metílico associados a fungicidas para o controle de doenças foliares na cultura da soja. Tropical Plant Pathology, v. 38, n. 1, p .072-077, 2013. Available from: <https://doi.org/10.1590/S1982-56762013000100012>. Accessed: Jan. 13, 2021. doi: 10.1590/S1982-56762013000100012.

STADNIK, M. J.; FREITAS, M. B. D. Algal polysaccharides as source of plant resistance inducers. Tropical Plant Pathology, v.39 n.2, p.111-118, 2014. Available from: <https://doi.org/10.1590/ S1982-56762014000200001>. Accessed: Jul. 08, 2020. doi: $10.1590 / \mathrm{S} 1982-56762014000200001$.

TANDON, S.; DUBEY, A. Effects of Biozyme (Ascophyllum nodosum) biostimulant on growth and development of soybean [Glycine $\max ($ L.) Merill]. Communications in Soil Science and Plant Analysis, v.46, n.7, p.845-858, 2015. Available from: <https://www.tandfonline.com/doi/full/10.1 080/00103624.2015.1011749>. Accessed: Jul. 15, 2020. doi: $10.1080 / 00103624.2015 .1011749$

ZDZIARSKI, A. D. et al. Mega environment identification for soybean (Glycine max) breeding and production in Brazilian Midwest region. Plant Breeding, v.138, n.3, p.336-347, 2019. Available from: https://onlinelibrary.wiley.com/doi/abs/10.1111/ pbr.12693 Accessed: Jul. 25, 2020. doi:10.1111/pbr.12693.

WRÓBEL-KWIATKOWSKA, M. et al. Expression of $\beta-1,3-$ glucanase in flax causes increased resistance to fungi. Physiological and Molecular Plant Pathology, v.65, n.5, p.245-256, 2004. Available from: <https://doi.org/10.1016/j.pmpp.2005.02.008>. Accessed: Jul. 25, 2020. doi: 10.1016/j.pmpp.2005.02.008. 